\title{
Peningkatan Aktivitas Belajar Pendidikan Agama Islam Melalui Metode Diskusi Terpimpin Murid Kelas V Sekolah Dasar Negeri 001 Bangkinang Seberang
}

\author{
Akmal Taufik*, Zulkifli** \\ * Universitas Islam Negeri Sultan Syarif Kasim Riau, Pekanbaru \\ akmal.taufik@gmail.com \\ ** Universitas Islam Negeri Sultan Syarif Kasim Riau, Pekanbaru \\ zulkifli@uin-suska.ac.id
}

\section{INFO ARTIKEL}

\section{Riwayat Artikel:}

Diterima: 12 Oktober 2018

Disetujui: 25 Juni 2019

\section{Kata kunci:}

Aktivitas Belajar

Pendidikan Agama Islam

Metode Diskusi

\section{Alamat Korespondensi:}

Zulkifli,

Universitas Islam Negeri Sultan Syarif Kasim Riau, Pekanbaru

Email: zulkifli@uin-suska.ac.id

\section{LATAR BELAKANG}

Dalam proses pendidikan guru merupakan salah satu faktor yang menentukan terhadap keberhasilan muridnya dengan demikian guru dalam pelaksanaan proses belajar mengajar tidak hanya dituntut agar mampu menyampaikan materi pelajaran dan menguasai bahan pelajaran tetapi harus dapat mengaktifkan diskusi terpimpin murid dalam proses belajar mengajar. Guru hendaknya selalu berusaha memberikan bimbingan dan selalu mendorong semangat belajar anak didik, mengorganisasikan kegiatan belajar sebaik mungkin dan menjadi media informasi yang sangat dibutuhkan murid dibidang pengetahuan, keterampilan dan perilaku atau sikap (Ramayulis, 1994). Termasuk didalamnya meningkatkan aktivitas belajar Pendidikan Agama Islam. Belajar pada hakikatnya merupakan suatu 
rangkaian kegiatan yang menuntut keaktifan baik guru maupun murid. Jadi tampak jelas adanya guru aktif mengajar di satu pihak, dan murid aktif belajar di lain pihak. Konsep ini bersumber dari teori kurikulum yang berpusat pada anak (Child Centered Curriculum). Penerapannya berlandaskan kepada teori belajar yang menekankan pentingnya belajar melalui proses mengalami untuk memperolah pemahaman. Di samping itu, belajar juga merupakan hasil dari proses interaksi antara diri individu dan lingkungan sekitarnya. Belajar tidak hanya semata-mata sebagai suatu upaya dalam merespon suatu rangsangan.

Tetapi lebih dari pada itu, belajar dilakukan melalui berbagai kegiatan seperti mengalami, mengajarkan, dan memahami belajar melalui proses (learning by process). Jadi, hasil belajar dapat diperoleh bila murid "aktif, tidak pasif (Ali, 1987). Untuk mewujudkan tujuan tersebut guru mempunyai fungsi yang sangat penting dan sangat menentukan dalam proses pembelajaran. Seorang guru yang profesional dituntut agar dapat menyampaikan materi pelajaran dengan baik, efektif dan efisien sehingga murid sebagai peserta didik mengerti dan memahami apa yang disampaikannya. Guru dituntut pula menguasai berbagai strategi pembelajaran agar suasana pembelajaran di kelas lebih bergairah dan menyenangkan. M. Daud Ali (2006) menyatakan bahwa mempelajari agama Islam merupakan kewajiban bagi setiap pemeluk agama Islam, karena mempelajari ajaran agama Islam hukumnya adalah fardu 'ain, yakni kewajiban bagi setiap pribadi muslim dan muslimah, sedangkan mengkaji ajaran Islam, terutama yang dikembangkan oleh akal pikiran manusia, diwajibkan kepada masyarakat atau kelompok masyarakat untuk mempelajarinya.

Sebaiknya di Sekolah Dasar Negeri 001 Pulau Kecamatan Bangkinang Seberang Kabupaten Kampar, guru dalam melaksanakan pembelajaran mampu memilih dan menerapkan strategi pembelajaran yang efektif yang dapat mendukung kepada hasil pembelajaran. Mulai dari aktifitas belajar murid di kelas, suasana belajar yang kondusip interaksi guru dengan murid, murid dengan murid dan sebagainya. Pada dasarnya banyak usaha yang telah dilakukan oleh guru di Sekolah Dasar Negeri 001 Pulau Kecamatan Bangkinang Seberang Kabupaten Kampar untuk meningkatkan aktivitas belajar murid kelas $\mathrm{V}$ diantaranya adalah dengan menerapkan metode ceramah, pemberian tugas dan metode latihan. Namun berdasarkan observasi awal peneliti di Sekolah Dasar Negeri 001 Pulau Kecamatan Bangkinang Seberang Kabupaten Kampar masih ditemui gejala-gejala atau fenomena khususnya di kelas V pada pelajaran Pendidikan Agama Islam sebagai berikut: 1) hanya sebagian murid yang mengajukan pertanyaan baik kepada guru maupun kepada murid lainnya; 2) sebagian murid yang mengajukan pendapat terhadap informasi yang disampaikan oleh guru atau murid lain; 3) murid kurang memberikan respon yang nyata setelah guru menyampaikan materi stelah proses belajar mengajar dilaksanakan; dan 4) sebagian murid membuat kesimpulan pelajaran dengan bahasanya sendiri. Dari gejala-gejala tersebut terlihat bahwa pembelajaran yang dilaksanakan oleh guru pada mata pelajaran Pendidikan Agama Islam, kurang meningkatkan aktivitas belajar yang optimal. Menurut peneliti ini disebabkan karena kurangnya kreatifitas guru menciptakan suasana belajar yang efektif, kreatif dan kondusif dalam proses pembelajaran. Salah satu metode yang dapat digunakan dalam meningkatkan aktifitas belajar siswa adalah metode diskusi terpimpin.

Menurut Mulyasa (2007) bahwa diskusi terpimpin merupakan salah satu bentuk kegiatan pembelajaran yang sering digunakan, yang melibatkan sekitar 3 sampai lima orang peserta dalam setiap kelompok, berlangsung secara informal sehingga setiap anggota dapat berkomunikasi langsung dengan anggota lain dan memiliki tujuan yang dicapai dengan kerja sama antar anggota kelompok. Roestiyah (2001) mengatakan bahwa metode diskusi adalah salah satu teknik belajar mengajar yang dilakukan oleh seorang guru di sekolah. Di dalam diskusi ini proses interaksi antara dua atau lebih individu yang terlibat, salah, dapat terjadi juga semuanya aktif tidak ada yang pasif sebagai pendengar saja. Penerapan metode diskusi mempunyai beberapa keunggulan, di antaranya adalah sebagai berikut: 1) dapat mempertinggi partisipasi murid secara individual;2) dapat mempertinggi kegiatan kelas sebagai keseluruhan dan kesatuan; 3) rasa sosial mereka dapat dikembangkan, kerena bisa saling membantu dalam memecahkan soal, mendorong rasa kesatuan; 4) memberi kemungkinan untuk saling mengemukakan pendapat; dan 5) merupakan pendekatan yang demokratis. Selain itu, penerapan metode diskusi juga mempunyai beberapa kelemahan, di antaranya adalah sebagai berikut: 1) kadang-kadang bisa terjadi adanya pandangan dari berbagai sudut bagi masalah yang dipecahkan, bahkan mungkin pembicaraan menjadi menyimpang, sehingga memerlukan waktu yang panjang, untuk mengatasi hal ini instruktur harus menguasai benar-benar permasalahannya, dan mampu mengarahkan pembicaraan, sehingga bisa membatasi waktu yang diperlukan; 2) dalam menghadapi pembuktian logis, yang tidak terlepas dari fakta-fakta, dan tidak merupakan jawaban yang hanya dugaan atau coba-coba saja. Maka pada murid dituntut kemampuan berfikir ilmiah, hal itu tergantung pada kematangan, pengalaman dan pengetahuan murid; 3) tidak dapat dipakai pada kelompok yang besar; dan 4) peserta mendapat informasi yang terbatas (Roestiyah, 2001).

Menurut Suryosubroto (2002) bahwa diskusi dapat dilakukan dalam bermacam-macam bentuk dan dengan bermacam-macam tujuan. Berbagai bentuk diskusi yang terkenal adalah sebagai berikut: 1) The Social Problema Meeting, para murid berbincang-bincang memecahkan masalah sosial di kelasnya atau di sekolahnya dengan harapan setiap murid akan merasa terpanggil untuk mempelajari dan bertingkah laku sesuai dengan kaidah-kaidah yang berlaku, seperti dengan guru atau personel sekolah lainnya, peraturan-peraturan di kelas, hak-hak dan kewajibannya di kelas/di sekolah; 2) The open-ended meeting, para murid berbincang-bincang mengenai masalah apa saja yang 
berhubungan dengan kehidupan mereka sehari-hari dengan kehidupan mereka di sekolah, dengan sesuatu yang terjadi dilingkungan sekitar mereka, dan sebagainya; dan 3) The eductional-diagnosis meeting, para murid berbincangbincang mengenai pelajaran di kelas dengan maksud untuk saling mengoreksi pemahaman mereka atas pelajaran yang telah diterimanya agar masing-masing anggota memperoleh pemahaman yang lebih baik/benar. Berdasarkan penjelasan tersebut, jelaslah bahwa teknik diskusi terdiri dari bermacam-macam model. Variasi tersebut tergantung pada jumlah kelompok maupun proses pelaksanaan diskusi itu sendiri. Sehubungan dengan penelitian ini, maka teknik diskusi yang dimaksud adalah bentuk diskusi The eductional-diagnosis meeting, dimana para murid berbincangbincang mengenai pelajaran di kelas dengan maksud untuk saling mengoreksi pemahaman mereka atas pelajaran yang telah diterimanya agar masing-masing anggota memperoleh pemahaman yang lebih benar. Adapun jumlah murid dalam diskusi kelompok kecil adalah 3 sampai 5 orang.

Oleh sebab itu, artikel ini memiliki tujuan untuk mengetahui Peningkatan Aktivitas Belajar Pendidikan Agama Islam Melalui Metode Konsep Diskusi Terpimpin Murid Kelas V Sekolah Dasar Negeri 001 Pulau Kecamatan Bangkinang Seberang Kabupaten Kampar.

\section{METODE}

Artikel ini menggunakan jenis penelitian ini adalah penelitian tindakan kelas yang dilaksanakan di dilaksanakan di Sekolah Dasar Negeri 001 Pulau Kecamatan Bangkinang Seberang Kabupaten Kampar. Sebagai subjek dalam penelitian ini adalah guru dan murid kelas V tahun pelajaran 2011-2012 dengan jumlah murid sebanyak 39 orang. Sedangkan sebagai objek dalam penelitian ini adalah penerapan metode diskusi terpimpin untuk meningkatkan aktivitas belajar murid dalam mata pelejaran Pendidikan Agama Islam. Penelitian ini terdiri dari 2 siklus. Setiap siklus dilakukan dalam 2 kali pertemuan. Hal ini dimaksudkan agar murid dan guru dapat berdaptasi dengan strategi pembelajaran yang diterapkan. Sehingga hasil penelitian tindakan kelas dapat dimanfaatkan dalam proses belajar mengajar selanjutnya. Terdapat beberapa tahapan yang harus dilaksanakan dalam penelitian ini agar penelitin ini dapat berjalan dengan baik dan dapat mencapai hasil yang maksimal. Adapun tahapan-tahapan yang dilalui dalam penelitian tindakan kelas, yaitu: 1) perencanaan/persiapan tindakan; 2) pelaksanaan tindakan; 3) observasi; dan 4) refleksi. Data yang diperoleh dalam artikel ini dikumpulkan dengan menggunakan teknik observasi. Untuk mengukur Aktivitas belajar pada mata pelajaran Pendidikan Agama Islam, penulis menggunakan rumus persentase (Sudjono, 2004). Dalam menentukan kriteria penilaian tentang hasil penelitian aktivitas guru, aktivitas murid dan motivasi belajar selama proses pembelajaran dengan penerapan metode artikulasi, maka dilakukan pengelompokkan atas 4 kriteria penilaian yaitu baik, cukup, kurang baik dan tidak baik.

\section{HASIL}

\section{Data Sebelum Tindakan}

Berdasarkan dari hasil analisis terhadap Keaktifan belajar murid kelas v Sekolah Dasar Negeri 001 Pulau Kecamatan Bangkinang Seberang sebelum dilakukannya tindakan, diketahui bahwa Keaktifan belajar murid dalam pelajaran Pendidikan Agama Islam tergolong sedang dengan jumlah rata-rata persentase 43,2\%. Analisis sementara penulis, rendahnya Keaktifan murid dalam belajar Agama Islam disebabkan karena kurang mampunya guru memilih dan menerapkan metode atau strategi pembelajaran yang tepat sehingga pada kenyataannya nilai yang diharapkan masih tergolong rendah. Berdasarkan analisis data yang dilakukan, diketahui bahwa aktivitas belajar murid dalam pelajaran Pendidikan Agama Islam secara klasikal masih tergolong sedang dengan perolehan skor 320 dengan rata-rata 49,2\%, angka persentase tersebut berada pada interval 40\%-55\%. Oleh karena itu, peneliti melakukan langkah perbaikan untuk masalah rendahnya aktivitas belajar murid dalam pelajaran Pendidikan Agama Islam dengan metode diskusi terpimpin. Karena peneliti merasa dengan melihat langkah-langkah pembelajaran metode diskusi terpimpin aktivitas belajar murid khususnya pada mata pelajaran PAI akan dapat meningkat. Untuk lebih jelasnya penulis akan menguraikan peningkatan aktivitas belajar PAI murid melalui penerapan metode diskusi terpimpin.

Secara rinci Indikator keaktifan belajar murid pada bidang studi Pendidikan Agama Islam adalah sebagai berikut: 1) murid tidak hanya menerima informasi tetapi lebih banyak mencari dan memberikan informasi, diperoleh nilai rata-rata persentase $47,7 \% ; 2$ ) murid banyak mengajukan pertanyaan baik kepada guru maupun kepada murid lainnya, diperoleh nilai rata-rata persentase $48,5 \%$; 3 ) murid lebih banyak mengajukan pendapat terhadap informasi yang disampaikan oleh guru atau murid lain, diperoleh nilai rata-rata persentase 51,5\%; 4) murid mengerjakan tugas yang diberikan oleh guru, diperoleh nilai rata-rata persentase 47,7\%; dan 5) murid berkesempatan melakukan penilaian sendiri terhadap hasil pekerjaannya, sekaligus memperbiki dan menyempurnakan hasil pekerjaan yang belum sempurna, diperoleh nilai rata-rata persentase $50,8 \%$.

\section{Siklus 1}

Setelah pelaksanaan tindakan selesai dilaksanakan, maka dilakukan observasi untuk mengukur aktivitas belajar murid dalam pelajaran PAI. Hasil analisis menunjukkan bahwa aktivitas belajar murid pada siklus pertama dalam 
pelajaran PAI murid secara klasikal tergolong tinggi dengan perolehan rata-rata persentase $66,2 \%$, angka ini berada pada interval 56-75. interval ini berada pada kategori sedang. Kemudian persentase aktivitas belajar pada tiap aspek dapat dilihat pada keterangan di bawah ini: 1) murid yang di tunjuk oleh guru menjadi ketua, sekretaris, dan moderator maju ke tempat yang telah di sediakan dengan baik dan tertib diperoleh nilai rata-rata persentase 50,8\%; 2) masing-masing anggota mengajukan pendapatnya dengan baik dan benar, diperoleh nilai rata-rata persentase $50 \%$; 3) murid memperhatikan rangkuman yang di buat oleh guru dari pendapat masing-masing anggota dengan baik dan seksama., diperoleh nilai rata-rata persentase 52,3\%; 4) murid mendengarkan kesimpulan yang dibuat oleh guru tentang materi pelajaran yang telah di diskusikan., diperoleh nilai rata-rata persentase 50.8\%; dan 5) murid mendengarkan guru dalam merumuskan tindak lanjut dengan baik dan seksama., diperoleh nilai rata-rata persentase $50.8 \%$. Sedangkan hasil observasi aktivitas belajar murid pada siklus I pertemuan 2 mengalami peningkatan.

Hasil menunjukkan bahwa aktivitas belajar murid pada siklus pertama pertemuan II dalam pelajaran PAI murid secara klasikal tergolong tinggi dengan perolehan rata-rata persentase 56,4\%, angka ini berada pada interval 56-75. interval ini berada pada kategori tinggi. Kemudian persentase aktivitas belajar pada tiap aspek dapat dilihat pada keterangan di bawah ini: 1)murid yang di tunjuk oleh guru menjadi ketua, sekretaris, dan moderator maju ke tempat yang telah di sediakan dengan baik dan tertib diperoleh nilai rata-rata persentase 55,4\%;2) masing-masing anggota mengajukan pendapatnya dengan baik dan benar, diperoleh nilai rata-rata persentase $55,4 \%$; 3) murid memperhatikan rangkuman yang di buat oleh guru dari pendapat masing-masing anggota dengan baik dan seksama., diperoleh nilai rata-rata persentase $56,9 \%$; 4) murid mendengarkan kesimpulan yang dibuat oleh guru tentang materi pelajaran yang telah di diskusikan., diperoleh nilai rata-rata persentase $55,4 \%$; dan 5) murid mendengarkan guru dalam merumuskan tindak lanjut dengan baik dan seksama., diperoleh nilai rata-rata persentase $58,5 \%$.

\section{Siklus 2}

Setelah pelaksanaan tindakan selesai dilaksanakan, maka dilakukan observasi untuk mengukur aktivitas belajar murid dalam pelajaran PAI. Hasil menunjukkan bahwa aktivitas belajar murid pada siklus II pertemuan I dalam pelajaran PAI murid secara klasikal tergolong sangat tinggi dengan perolehan rata-rata persentase $60,15 \%$, angka ini berada pada interval 76\%-100\%. interval ini berada pada kategori Sangat tinggi. Kemudian persentase aktivitas belajar pada tiap aspek dapat dilihat pada keterangan di bawah ini: 1) murid yang di tunjuk oleh guru menjadi ketua, sekretaris, dan moderator maju ke tempat yang telah di sediakan dengan baik dan tertib diperoleh nilai rata-rata persentase $59,2 \%$; 2) masing-masing anggota mengajukan pendapatnya dengan baik dan benar, diperoleh nilai ratarata persentase $60 \%$; 3) murid memperhatikan rangkuman yang di buat oleh guru dari pendapat masing-masing anggota dengan baik dan seksama., diperoleh nilai rata-rata persentase $59,2 \% ; 4)$ murid mendengarkan kesimpulan yang dibuat oleh guru tentang materi pelajaran yang telah di diskusikan., diperoleh nilai rata-rata persentase $61,5 \%$; dan 5) murid mendengarkan guru dalam merumuskan tindak lanjut dengan baik dan seksama., diperoleh nilai ratarata persentase $60,8 \%$. Sedangkan hasil observasi aktivitas belajar murid pada siklus II pertemuan II mengalami pengkatan persentase menjadi $65,8 \%$.

Kemudian persentase aktivitas belajar pada tiap aspek dapat dilihat pada keterangan di bawah ini: 1) murid yang di tunjuk oleh guru menjadi ketua, sekretaris, dan moderator maju ke tempat yang telah di sediakan dengan baik dan tertib diperoleh nilai rata-rata persentase $63,8 \%$; 2) masing-masing anggota mengajukan pendapatnya dengan baik dan benar, diperoleh nilai rata-rata persentase $63,8 \%$; 3) murid memperhatikan rangkuman yang di buat oleh guru dari pendapat masing-masing anggota dengan baik dan seksama., diperoleh nilai rata-rata persentase $61,5 \%$; 4) murid mendengarkan kesimpulan yang dibuat oleh guru tentang materi pelajaran yang telah di diskusikan., diperoleh nilai rata-rata persentase 67,7\%; dan 5) murid mendengarkan guru dalam merumuskan tindak lanjut dengan baik dan seksama., diperoleh nilai rata-rata persentase $68,5 \%$. Refleksi siklus pertama diperoleh berdasarkan hasil analisis data untuk tiap-tiap langkah pelaksanaan tindakan yang akan dideskripsikan peneliti pada tahap ini. Selanjutnya didiskusikan dengan observer, yang berperan sebagai observer yaitu teman sejawat. Adapun refleksi siklus pertama adalah sebagai berikut: Rata-rata aktivitas guru pada pertemuan pertama masih dikategorikan tinggi dengan persentase $64 \%$, Namun pada pertemuan 2, rata-rata persentase aktivitas guru meningkat menjadi $84 \%$. Setelah diambil nilai ratarata nya, diperoleh angaka $74 \%$. Oleh karena itu guru tidak perlu mengadakan tindakan perbaikan dalam proses pembelajaran berikutnya.

\section{PEMBAHASAN \\ Aktivitas Belajar Murid}

Dari hasil observasi disimpulkan bahwa aktivitas belajar murid dalam pendidikan Agama Islam dengan penerapan Metode diskusi terpimpin mengalami peningkatan dibandingkan sebelum tindakan. Hal ini ditunjukkan dengan angka persentase $77,1 \%$ secara klasikal setelah tindakan yaitu pada siklus II pertemuan 1 dan pertemuan 2 . Untuk lebih jelasnya dapat dilihat pada tabel rekapitulasi berikut ini. 
28 Instructional Development Journal (IDJ), Vol. 2, No. 1, Juni 2019, Hal. 23-29

Tabel 1. Rekapitulasi Hasil Observasi Aktivitas Belajar Murid Sebelum Tindakan

\begin{tabular}{cccccccc}
\hline \multirow{2}{*}{ NO } & \multirow{2}{*}{ Tindakan } & \multicolumn{5}{c}{ Indikator } \\
\cline { 4 - 8 } & & 1 & 2 & 3 & 4 & 5 \\
\hline \multirow{2}{*}{1} & $\begin{array}{l}\text { Sebelum } \\
\text { tindakan }\end{array}$ & Jumlah & 62 & 63 & 67 & 62 & 66 \\
& & Persentase & 47.69 & 48.46 & 51.54 & 47.69 & 50.77 \\
\hline
\end{tabular}

Dari hasil observasi disimpulkan bahwa aktivitas belajar murid dalam pendidikan Agama Islam dengan penerapan Metode diskusi terpimpin sebelum tindakan adalah rata-rata 49,23\%.

Tabel 2. Rekapitulasi Hasil Observasi Aktivitas Belajar Murid Siklus I

\begin{tabular}{|c|c|c|c|c|c|c|c|}
\hline \multirow{2}{*}{$\mathrm{NO}$} & \multirow{2}{*}{\multicolumn{2}{|c|}{ Siklus I }} & \multicolumn{5}{|c|}{ Indikator } \\
\hline & & & 1 & 2 & 3 & 4 & 5 \\
\hline \multirow[t]{2}{*}{1} & Pertemuan Pertama & Jumlah & 66 & 65 & 68 & 66 & 66 \\
\hline & & Persentase & 50.8 & 50.0 & 52.3 & 50.8 & 50.8 \\
\hline \multirow[t]{2}{*}{2} & Pertemuan Kedua & Jumlah & 72 & 72 & 74 & 72 & 76 \\
\hline & & Persentase & 55.4 & 55.4 & 56.9 & 55.4 & 58.5 \\
\hline
\end{tabular}

Dari hasil observasi disimpulkan bahwa aktivitas belajar murid dalam pendidikan Agama Islam dengan penerapan Metode diskusi terpimpin pada siklus satu mengalami peningkatan dibandingkan dengan sebelum tindakan adalah rata-rata $53,71 \%$.

Tabel 3. Rekapitulasi Hasil Observasi Aktivitas Belajar Murid Siklus II

\begin{tabular}{|c|c|c|c|c|c|c|c|}
\hline \multirow{2}{*}{$\mathrm{NO}$} & \multirow{2}{*}{\multicolumn{2}{|c|}{ Siklus II }} & \multicolumn{5}{|c|}{ Indikator } \\
\hline & & & 1 & 2 & 3 & 4 & 5 \\
\hline \multirow[t]{2}{*}{1} & Pertemuan Pertama & Jumlah & 77 & 78 & 77 & 80 & 79 \\
\hline & & Persentase & 59.2 & 60.0 & 59.2 & 61.5 & 60.8 \\
\hline \multirow[t]{2}{*}{2} & Pertemuan Kedua & Jumlah & 83 & 83 & 80 & 88 & 89 \\
\hline & & Persentase & 63.8 & 63.8 & 61.5 & 67.7 & 68.5 \\
\hline
\end{tabular}

Dari hasil observasi disimpulkan bahwa aktivitas belajar murid dalam pendidikan Agama Islam dengan penerapan Metode diskusi terpimpin pada siklus satu mengalami peningkatan dibandingkan dengan sebelum tindakan adalah rata-rata $62,62 \%$. Meningkatnya aktivitas belajar murid pada siklus II dibandingkan pada siklus I menunjukkan bahwa perbaikan pembelajaran dapat memecahkan permasalahan yang dihadapi. Artinya, perencanaan pembelajaran yang dibuat sesuai untuk mengatasi permasalahan rendahnya aktivitas belajar murid yang terjadi di dalam kelas selama ini. lebih lanjut, adanya peningkatan aktivitas belajar murid pada mata pelajaran PAI dari sebelumnya ke siklus I dan ke siklus II menunjukkan bahwa melalui Metode diskusi terpimpin dapat meningkatkan aktivitas belajar murid dalam pelajaran PAI Pada Materi menceritakan kisah Nabi murid kelas V SDN 001 Pulau Kecamatan Bangkinang Seberang Kabupaten Kampar Tahun 2011-2012.

\section{SIMPULAN DAN SARAN}

\section{Simpulan}

Berdasarkan hasil pembahasan dan analisis seperti disampaikan pada bab IV dapat disimpulkan bahwa melalui penerapan Metode Diskusi Terpimpin, maka akan dapat meningkatkan aktivitas Belajar pada pelajaran PAI murid kelas V SDN 001 Pulau Kecamatan Bangkinang Seberang Kabupaten Kampar. Keberhasilan ini dapai tercapai dipengaruhi oleh pengunaan Metode Dsikusi Terpimpin, aktivitas murid menjadi lebih aktif yang berarti murid cenderung positif dalam mengikuti proses pembelajaran yang diberikan oleh guru. Dengan demikian maka tingkat penerimaan murid akan meningkat dan pada gilirannya dapat meningkatkan aktivitas belajar murid. Berdasarkan dari hasil penelitian di atas, dapat digambarkan bahwa secara keseluruhan aktivitas guru dalam penggunaan Metode diskusi terpimpin dari siklus I pertemuan pertama yaitu 56\% dan pertemuan kedua mengalami peningkatan menjadi $72 \%$ mengalami peningkatan. Aktivitas guru dalam penggunaan Metode diskusi terpimpin pada siklus II pertemuan pertama $76 \%$ dan pertemuan kedua mengalami peningkatan menjadi $92 \%$. Sedangkan aktivitas. Dari hasil penelitian pada siklus I pertemuan pertama dan kedua dijelaskan bahwa aktivitas belajar murid pada siklus 
pertama dalam pelajaran PAI murid tinggi dengan perolehan rata-rata persentase 53.62\%, angka ini berada pada interval 40-55. interval ini berada pada kategori sedang.

\section{Saran}

Bertolak dari kesimpulan dan pembahasan hasil penelitian di atas, berkaitan dengan Metode Diskusi Terpimpin yang telah dilaksanakan, peneliti memberikan beberapa saran, yaitu: 1) agar penerapan Metode Diskusi Terpimpin tersebut dapat berjalan dengan baik, maka sebaiknya guru lebih sering menerapkannya dalam proses pembelajaran, khususnya pada pelajaran PAI; dan 2) anak dibiasakan berkomunikasi dengan bahasanya sendiri melalui diskusi terpimpin.

\section{DAFTAR RUJUKAN}

Anas Sudjono, (2004), Pengantar Statistik Pendidikan, Jakarta: Raja Grafindo Persada.

Muhammad Ali, (1987), Guru Dalam Proses Belajar Mengajar, Bandung: Sinar Baru.

Muhammad Daud Ali, (2006), Pendidikan Agama Islam, Jakarta: PT. Grafindo Persada.

Mulyasa, (2007), Menjadi Guru Profesional, Bandung: PT. Remaja Rodakarya.

Nana Sudjana, (1989), CBSA Dalam Proses Belajar Mengajar, Sinar Baru: Bandung.

Rahmayulis, (2002), Ilmu Pendidikan Islam, Jakarta: Kalamulia.

Ramayulis, (1994), Metodologi Pengajaran Agama Islam, Jakarta: Kalam Mulia.

Roestiyah, (2001), Strategi Belajar Mengajar, Jakarta: PT. Rineka Cipta.

Suharsimi Arikunto, (1998), Prosedur Penelitian Suatu Pendekatan Praktek, Jakarta: Rineka Cipta.

Suryosubroto, (2002), Proses Belajar Mengajar di Sekolah, Jakarta: Rineka Cipta 